\title{
Synergetic Antimicrobial Effects of Mixtures of Ethiopian Honeys and Ginger Powder Extracts on Standard and Resistant Clinical Bacteria Isolates
}

\author{
Yalemwork Ewnetu, ${ }^{1}$ Wossenseged Lemma, ${ }^{2}$ and Nega Birhane ${ }^{1}$ \\ ${ }^{1}$ Department of Biotechnology, Natural and Computational Sciences Faculty, University of Gondar, Gondar, Ethiopia \\ ${ }^{2}$ Department of Parasitology, School of Biomedical and Laboratory Sciences, College of Medicine and Health Sciences, \\ University of Gondar, P.O. Box 196, Gondar, Ethiopia
}

Correspondence should be addressed to Wossenseged Lemma; wossensegedlemma@yahoo.com

Received 26 November 2013; Revised 3 February 2014; Accepted 10 February 2014; Published 17 March 2014

Academic Editor: Sunil Kumar Khare

Copyright (C) 2014 Yalemwork Ewnetu et al. This is an open access article distributed under the Creative Commons Attribution License, which permits unrestricted use, distribution, and reproduction in any medium, provided the original work is properly cited.

\begin{abstract}
Purpose. To evaluate antimicrobial effects of mixtures of Ethiopian honeys and ginger rhizome powder extracts on Staphylococcus aureus (ATCC 25923), Escherichia coli (ATCC 25922), Staphylococcus aureus (MRSA), Escherichia coli (R), and Klebsiella pneumoniae (R). Methods. Agar diffusion and broth assays were performed to determine susceptibility of these standard and resistant clinical bacteria isolates using honey-ginger powder extract mixtures. Results. Honey-ginger powder extract mixtures produced the highest mean inhibition $(25.62 \mathrm{~mm} \pm 2.55)$ compared to the use of honeys $(21.63 \mathrm{~mm} \pm 3.30)$ or ginger extracts $(19.23 \mathrm{~mm} \pm 3.42)$ individually. The ranges of inhibitions produced by honey-ginger extract mixtures on susceptible test organisms (26-30 $\mathrm{mm}$ ) and resistant strains (range: 19-27 mm) were higher compared to 7-22 $\mathrm{mm}$ and 0-14 mm by standard antibiotic discs. Minimum inhibitory concentrations (MIC) of mixture of honeys-ginger extracts were $6.25 \%(0.625 \mathrm{v} / \mathrm{mL})$ on the susceptible bacteria compared to $75 \%$ for resistant clinical isolates. Minimum bactericidal concentration (MBC) of honey-ginger extracts was $12.5 \%(0.125 \mathrm{~g} / \mathrm{mL})$ for all the test organisms. Conclusion. The result of this study showed that honey-ginger powder extract mixtures have the potential to serve as cheap source of antibacterial agents especially for the drug resistant bacteria strains.
\end{abstract}

\section{Introduction}

Plants have been used as a source of therapeutic agents in traditional medicinal system since ancient time due to bioactive compounds they contain $[1,2]$. The world health organization (WHO) has described traditional medicine as cheap way to achieve total health care coverage of the world's population and has encouraged the rational use of plant based traditional medicines by member states $[3,4]$. In Ethiopia, one of the developing countries, about $80 \%$ of the total population relies on traditional remedies as a primary source of health care $[3,5]$. Recently, indiscriminate use of antimicrobial drugs to treat the infectious diseases resulted in the development of resistant pathogenic bacteria strains like drug resistant Escherichia coli, Klebsiella pneumonia, and Staphylococcus aureus [6]. Multidrug resistant pathogenic bacteria strains in hospitals and community are the main cause of mortality and morbidity [6-8]. The increasing resistance bacteria against the existing antibiotics resulted in many studies to focus on antimicrobial agents derived from plants [9-12]. Traditional medicine has become a form of complementary medicine and holds a great promise as source of effective therapy for multiple drug resistant strains of bacteria $[13,14]$.

Ginger has several ethnomedicinal and nutritional values as spice and flavoring agents in Ethiopia and elsewhere $[15,16]$. In last few decades, gingeris extensively studied for its medicinal properties by advanced scientific techniques and a variety of bioactive compounds such as tannins, flavonoid, glycosides, essential oils, furostanol, spirostanol, saponins, phytosterols, amides, alkaloids have been isolated from the different parts of the plant which were analyzed pharmacologically $[9,10,17-19]$. The plant was reported 
for antimicrobial [10, 18-22], nephroprotective [22], antiinflammatory, and immunomodulatory [23] activities. Traditionally, ginger is reported totreatnausea, vomiting, asthma, cough, palpitation, inflammation, and dyspepsia, loss of appetite, constipation, indigestion, and pain in different parts of the world [24]. Similarly, ginger is used, traditionally, for treating common cold, stomachache, cough, fever, and influenza in Ethiopia [25, 26]. Mixtures of ginger rhizome powder and honeys are also used to treat different types of respiratory and gastrointestinal infections in traditional medicine of Ethiopia. The Ethiopian honeys have also been found effective in producing antibacterial effects on susceptible and resistant strains of bacteria from clinical isolates in Ethiopia [27]. The net effect of herbal drug interactions can be additive, synergetic, or antagonistic [28]. The additive and synergetic effects of phytochemicals in fruit and vegetables are responsible for their potent antioxidant and anticancer activities [29]. The combined antibacterial activity of honeygarlic (Allium sativum) or fresh ginger leaves or rhizome extract mixtures was reported superior over the use of these antimicrobial agents individually $[12,30]$. Drug interactions of the antimicrobial agents contained in mixtures of Ethiopian honeys and dried ginger rhizome powder extracts were not evaluated. Study on the type of interactions of antimicrobial agents in mixtures of honey and ginger rhizome extract would give an insight about the advantage of using mixtures instead of using ginger or honeys individually. The aim of this study was to evaluate antibacterial effects of mixture of Ethiopian honeys (Apis mellifera and stingless bees honeys) and ginger powder ethanol/methanol extracts on standard and resistant clinical isolates of Staphylococcus aureus, Escherichia coli, and Klebsiella pneumoniae.

\section{Materials and Methods}

2.1. Study Area and Period. Honeys and ginger rhizomes were purchased in September and October, 2012, G.C from Gondar and Tigray regions in Ethiopia and their antimicrobial effects, including honey-ginger powder extract mixtures, were analyzed in biotechnology laboratory in Gondar University from September 20, 2012, to January 1, 2013.

2.2. Chemicals and Reagents. Methanol (B. Number A5791), Ethanol (Alpha chemical B Number M120415, India), Chloroform (BDH chemicals Ltd, Poole, lot Number 27710, England), Acetone, and distilled water were among the different chemicals and solvents used during this study.

2.3. Test Organisms. Standard and clinical isolates microorganisms such as Escherichia coli (ATCC 25922), Staphylococcus aureus (ATCC 25923), Escherichia coli (R), Methicillin resistance Staphylococcus aureus (MRSA), and Klebsiella pneumonia (R) were obtained from Gondar University teaching hospital laboratory.

2.4. Preparation of Honey-Ginger Extracts Solutions. Ginger rhizomes were washed with tape and distilled water and sliced into uniform pieces using sterile knife before drying in microoven at $37^{\circ} \mathrm{C}$ for 24 hours. The dried ginger pieces were crushed using electric grinder to obtain ginger powder. Different ginger extracts were obtained by adding $20 \mathrm{~g}$ of ginger powder into $100 \mathrm{~mL}$ methanol and ethanol as previous study [31]. Fifty percent ginger solution (50\% v/v) was obtained by dissolving $1 \mathrm{~mL}$ ginger extract in $1 \mathrm{~mL}$. Ginger powder water extract was considered as negative control as no inhibition zones were found in previous study [31]. The Ethiopian honeys were filtered using sterile gauze to get $100 \%$ pure honey. Honey-ginger mixtures will be prepared by mixing $1 \mathrm{~mL}$ of the ginger extract and $1 \mathrm{~mL}$ honey extract which will be diluted in $2 \mathrm{~mL}$ distilled water to obtain honeyginger extract solution $(50 \% \mathrm{v} / \mathrm{v})$.

2.5. Preparation of the Mueller Hinton Agar (MHA). Mueller Hinton agar (lot Number X4225F, oxoid, England) medium was prepared by dissolving $38 \mathrm{~g}$ of Mueller Hinton agar in $1000 \mathrm{~mL}$ distilled water and boil until complete dissolutions. The solution was sterilized in an autoclave $\left(121^{\circ} \mathrm{C}, 1\right.$ bar) for $15 \mathrm{~min}$. The suspension was poured $(20 \mathrm{~mL})$ into sterile petridishes in the hood to solidify at room temperature.

2.6. Preparation of the Nutrient Broth (7146). After dissolving $8 \mathrm{~g}$ nutrient broth powder in one liter of purified water, the mixture was mixed thoroughly to form a clear medium which would be incubated at $35^{\circ} \mathrm{C}$ for $18-24$ hours after the bacterial specimens were inoculated. Turbidity indicates good growth. Nutrient broth culture medium could live longer under refrigeration.

2.7. Preparation of Inoculations and Assays of Antibacterial Activities. The inoculation of the bacteria was done by streaking the surface of the plates with swab in a zigzag manner to spread the bacteria until the entire surface was covered. With a previously sterilized cork borer $(4 \mathrm{~mm})$ size, wells of equal distance were bored to drop $100 \mu \mathrm{L}$ of different ginger extracts and mixtures of honey-ginger powder extracts for agar diffusion assays. Hundred microliters $(100 \mu \mathrm{L})$ of the honey, ginger powder extract, and honey ginger extract mixtures at $50 \%(\mathrm{v} / \mathrm{v})$ concentration were inoculated into wells of Escherichia coli (ATCC 25922), Staphylococcus aureus (ATCC 25923), Escherichia coli (R), Staphylococcus aureus (MRSA), and Klebsiella pneumonia (R). The culture plates were incubated at $37^{\circ} \mathrm{C}$ for $24 \mathrm{~h}$. Inhibition zones were indicated by clear area around the wells which were measured in millimeters by caliper in order to evaluate the degree of susceptibility of the test organisms.

2.8. Preparation of 0.5 McFarland Standards and Standardization of Bacteria Concentration. In this study, $0.5 \mathrm{~mL}$ of $0.048 \mathrm{M} \mathrm{BaCl}_{2}\left(1.175 \% \mathrm{~W} / \mathrm{V} \mathrm{BaCl} \cdot 2 \mathrm{H}_{2} \mathrm{O}\right)$ was added to $99.5 \mathrm{~mL}$ of $0.18 \mathrm{M} \mathrm{H}_{2} \mathrm{SO}_{4}(1 \% \mathrm{~V} / \mathrm{V})$ with constant stirring to make $0.5 \mathrm{McF}$ arland Standards. The standard was distributed into a screw capped test tube for color comparison of the test inoculums. Hundred microliter $(100 \mu \mathrm{L})$ bacteria sample from nutrient broth culture media (lot Himedia laboratory, pvt, ltd., India) was added into $5 \mathrm{~mL}$ saline and the concentration was adjusted to $1-2 \times 10^{8}$ colony forming unit 
per milliliter $(\mathrm{Cfu} / \mathrm{mL})$ by comparing with McFarland 0.5 standardized.

2.9. Minimum Inhibitory Concentration (MIC) and Minimum Bactericidal Concentration (MBC). Hundred microliter $(100 \mu \mathrm{L})$ of bacteria samples from nutrient broth culture medium was added into $5 \mathrm{~mL}$ saline and the concentration was adjusted to $1-2 \times 10^{8} \mathrm{Cfu} / \mathrm{mL}$ by comparing with McFarland 0.5 standard with constant stirring before culturing in new broth medium to determine the lowest concentration of antimicrobial agent capable of preventing growth (Minimum inhibitory concentrations (MIC)). The inoculations of Escherichia coli (ATCC 25922), Staphylococcus aureus (ATCC 25923), Escherichia coli (R), Staphylococcus aureus (MRSA), and Klebsiella pneumonia (R) were done in different nutrient broth medium containing honey, ginger extract solutions, and mixtures honey-ginger extract solution. The tubes were incubated for $20-24$ hours at $37^{\circ} \mathrm{C}$ to observe turbidity (growth) which indicated the MIC of the honey, ginger extract, and honey-ginger extract mixtures on the test organisms. The minimum bactericidal concentrations (MBCs) were determined by subculturing the contents of nutrient broth used for MIC tests on Mueller Hinton agar media using sterile wire loop and making a strike on the media to see bacteria growth after incubating at $37^{\circ} \mathrm{C}$ for 24 hours. Absence of growth indicated the minimum bactericidal concentrations (MBCs) of the antimicrobial agents.

2.10. Drug Susceptibility. Drug susceptibility of standard Escherichia coli (ATCC 25922), Staphylococcus aureus (ATCC 25923), and resistant clinical isolates Escherichia coli (R), Staphylococcus aureus (MRSA), and Klebsiella pneumonia (R) cultures were determined using methicillin, amoxicillin, and penicillin discs by disc diffusion method. The result was interpreted as resistant, intermediate, or susceptible by comparing the results with what has already been reported by Clinical and Laboratory Standards Institute (CLSI) [32].

2.11. Statistical Analysis. The antibacterial effects (inhibitions) of honey, ginger extracts, and honey-ginger extracts mixtures were compared using descriptive statistics. All statistical analysis has been performed by using statistical package of social science (SPSS) version 20. Comparisons of honeys, ginger extracts, and honey-ginger extracts mixtures for their overall mean inhibitions were analyzed using oneway analysis of variance (ANOVA). $P$ values less than 0.05 were considered as significantly different. Further Tukey's Honestly Significant Difference (HSD) test or post hoc test was performed to see the effect of the antimicrobial agents on the individual bacteria strain.

\section{Results}

The overall comparison of the antimicrobial agents has shown that honey-ginger extract mixtures produced the highest mean inhibition $(25.62 \mathrm{~mm} \pm 2.55)$ for the total test organisms compared to the use of honeys $(21.63 \mathrm{~mm} \pm 3.30)$ or ginger extracts $(19.23 \mathrm{~mm} \pm 3.42)$ individually. The least

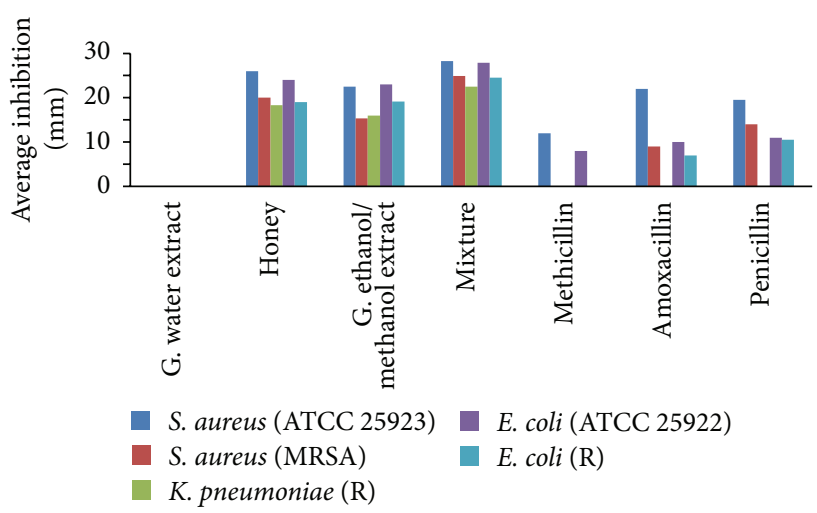

FIgURE 1: Average inhibition in $\mathrm{mm}$ for ginger powder water extracts, honeys, ginger powder ethanol/methanol extracts, mixture of honeys-ginger extracts, and standard antibiotic discs (Methicillin, Amoxicillin, and Penicillin).

mean inhibition result was obtained from the Methicillin antibiotic discs $(4 \mathrm{~mm} \pm 5.26)$ (Table 1). Mean inhibition of the honey-ginger extract mixture on susceptible bacteria isolates $(27.74 \mathrm{~mm} \pm 1.56)$ was higher compared to its effect on resistant isolates $(23.97 \mathrm{~mm} \pm 1.72)$. Similarly, the average inhibition of the honeys, ginger extracts, and honey-ginger extract mixtures was higher on susceptible bacteria strains compared to resistant clinical isolates (Figure 1). Ginger water extract did not produce any inhibition indicating the bioactive agents in the ginger powder are not water soluble. The overall mean inhibition of honeys of stingless bees and Apis mellifera was the same as statistical analysis using ANOVA and Tukey's Honestly Significant Difference (HSD) test (multiple comparison) which was greater than $0.05(P>$ 0.05). Similarly, ginger extracts using methanol and ethanol solvents showed no differences for their inhibitions on the test bacteria strains. But statistically significant difference was observed when overall mean inhibitions of honeys, ginger extracts, and honey-ginger extract mixtures were compared $(P=0.00)($ Table 1$)$.

The highest inhibition $(30 \mathrm{~mm})$ was produced by honeyginger extract mixtures on the susceptible bacteria strains. The range of inhibitions produced by honey-ginger extract mixtures on the susceptible bacteria isolates $(26-30 \mathrm{~mm})$ and resistant clinical isolates $(19-27 \mathrm{~mm})$ was also greater than $7-22 \mathrm{~mm}$ on susceptible or $0-14 \mathrm{~mm}$ on resistant isolates produced by the antibiotic discs (Methicillin, Amoxicillin, and Penicillin) (Table 1). When mean inhibition results on susceptible and resistant bacteria isolates were compared using ANOVA, there were statistically significant differences $(P=0.000)$ for honey, ginger extract, and honey-ginger extract mixture (Table 1).

Further Tukey's Honestly Significant Difference (HSD) test or post hoc test, however, showed absence of significant difference between mean inhibitions of susceptible on $S$. aureus (ATCC 25923) and E. coli (ATCC 25922) when honey $(P=0.964)$, ginger extract $(P=0.964)$, and honey-ginger mixture $(P=0.973)$ were used (Table 2). Similarly, no differences in mean inhibitions were found when the results 
TABLE 1: Results of one-way ANOVA and descriptive statistics of the inhibitions of honeys, ginger extracts, and honey-ginger extracts mixtures on the test bacteria isolates.

\begin{tabular}{|c|c|c|c|c|c|c|}
\hline Agents & Test organisms & $N$ & Mean & Standard deviation & Minimum & Maximum \\
\hline \multirow{6}{*}{ Honey* } & Staphylococcus aureus (ATCC 25923) & 6 & 22.50 & 1.64 & 21.00 & 24.00 \\
\hline & Staphylococcus aureus (MRSA) & 6 & 15.50 & 1.517 & 13.00 & 17.00 \\
\hline & Klebsiella pneumoniae(R) & 6 & 16.00 & 0.63 & 15.00 & 17.00 \\
\hline & Escherichia coli (ATCC 25922) & 6 & 23.00 & 1.27 & 21.00 & 24.00 \\
\hline & Escherichia coli (R) & 6 & 19.17 & 1.33 & 18.00 & 21.00 \\
\hline & Total & 30 & 19.23 & 3.42 & 13.00 & 24.00 \\
\hline \multirow{6}{*}{ Extract ${ }^{*}$} & Staphylococcus aureus (ATCC 25923) & 6 & 22.50 & 1.64 & 21.00 & 24.00 \\
\hline & Staphylococcus aureus (MRSA) & 6 & 15.50 & 1.52 & 13.00 & 17.00 \\
\hline & Klebsiella pneumoniae (R) & 6 & 16.00 & 0.63 & 15.00 & 17.00 \\
\hline & Escherichia coli (ATCC 25922) & 6 & 23.00 & 1.26 & 21.00 & 24.00 \\
\hline & Escherichia coli $(\mathrm{R})$ & 6 & 19.17 & 1.33 & 18.00 & 21.00 \\
\hline & Total & 30 & 19.23 & 3.42 & 13.00 & 24.00 \\
\hline \multirow{6}{*}{ Mixture* $^{*}$} & Staphylococcus aureus (ATCC 25923) & 12 & 28.25 & 1.14 & 27.00 & 30.00 \\
\hline & Staphylococcus aureus (MRSA) & 12 & 24.92 & 1.56 & 22.00 & 27.00 \\
\hline & Klebsiella pneumoniae (R) & 12 & 22.50 & 1.57 & 19.00 & 25.00 \\
\hline & Escherichia coli (ATCC 25922) & 12 & 27.92 & 1.38 & 26.00 & 30.00 \\
\hline & Escherichia coli (R) & 12 & 24.50 & 0.90 & 23.00 & 26.00 \\
\hline & Total & 60 & 25.62 & 2.55 & 19.00 & 30.00 \\
\hline \multirow{6}{*}{ Methicillin ${ }^{*}$} & Staphylococcus aureus (ATCC 25923) & 3 & 12.00 & 2.55 & 11.00 & 13.00 \\
\hline & Staphylococcus aureus (MRSA) & 3 & 0.00 & 1.00 & 0.00 & 0.00 \\
\hline & Klebsiella pneumoniae (R) & 3 & 0.00 & 0.00 & 0.00 & 0.00 \\
\hline & Escherichia coli (ATCC 25922) & 3 & 8.00 & 0.00 & 7.00 & 9.00 \\
\hline & Escherichia coli $(\mathrm{R})$ & 3 & 0.00 & 1.00 & 0.00 & 0.00 \\
\hline & Total & 12 & 4.00 & 0.00 & 0.00 & 13.00 \\
\hline \multirow{6}{*}{ Amoxicillin* } & Staphylococcus aureus (ATCC 25923) & 3 & 21.00 & 5.26 & 20.00 & 22.00 \\
\hline & Staphylococcus aureus (MRSA) & 3 & 10.00 & 1.00 & 9.00 & 11.00 \\
\hline & Klebsiella pneumoniae (R) & 3 & - & 1.00 & - & - \\
\hline & Escherichia coli (ATCC 25922) & 3 & 10.00 & - & 10.00 & 10.00 \\
\hline & Escherichia coli (R) & 3 & 8.00 & 0.00 & 7.00 & 9.00 \\
\hline & Total & 12 & 12.25 & 1.00 & 7.00 & 22.00 \\
\hline \multirow{7}{*}{ Penicillin* } & Staphylococcus aureus (ATCC 25923) & 3 & 20.00 & 5.40 & 19.50 & 20.50 \\
\hline & Staphylococcus aureus (MRSA) & 3 & 13.00 & 0.50 & 12.00 & 14.00 \\
\hline & Klebsiella pneumoniae (R) & 3 & - & 1.00 & - & - \\
\hline & Escherichia coli (ATCC 25922) & 3 & 10.00 & - & 9.00 & 11.00 \\
\hline & Escherichia coli (R) & 3 & 10.00 & 1.00 & 9.50 & 10.50 \\
\hline & Total & 12 & 13.25 & 0.50 & 9.00 & 20.50 \\
\hline & & & & 4.32 & & \\
\hline
\end{tabular}

${ }^{*}$ The mean difference is significant at the 0.05 level.

between the resistant $S$. aureus (MRSA) and E. coli (R) were compared for honey-ginger mixture alone $(P=0.940)$.

The minimum bactericidal concentration (MBC) for honeys, ginger extracts, and honey-ginger extract mixtures was $12.5 \%(0.125 \mathrm{~g} / \mathrm{mL})$. The bactericidal effect of this concentration was $100 \%$ for all test organisms. The minimum inhibitory concentrations (MIC) of honeys, ginger extracts, and honey-ginger extract mixtures were shown in Table 3. Honey-ginger extract mixtures have $6.25 \%(0.0625 \mathrm{~g} / \mathrm{mL})$ MIC values for all susceptible strains compared to $75 \%$ for resistant clinical isolates (Table 3).

\section{Discussion}

The ginger powder water extract (negative control) did not show bacterial growth inhibition on the test organisms (Figure 1) as it has already been reported [31]. But higher inhibition results were found for ginger ethanol or methanol extracts $(19.23 \mathrm{~mm} \pm 3.42)$ on the test organisms. The highest inhibition $(24 \mathrm{~mm})$ produced by this ginger powder extract on S. aureus (ATCC 25923) (Table 1) was less than $30 \mathrm{~mm}$ for S. aureus using fresh ginger rhizome ethanol extract in similar study [11]. This difference could be explained by the loss 
TABLE 2: Results of Tukey's Honestly Significant Difference (HSD) test of honey-ginger extract mixtures on the test bacteria isolates.

\begin{tabular}{|c|c|c|c|c|c|}
\hline Post hoc test & (I) spp. & $(J)$ spp. & Mean difference $(I-J)$ & Std error & Sig \\
\hline \multirow{20}{*}{ Mixture } & \multirow{5}{*}{$\begin{array}{l}\text { Staphylococcus aureus } \\
\text { (ATCC 25923) }\end{array}$} & $\begin{array}{c}\text { Staphylococcus aureus } \\
\text { (MRSA) }\end{array}$ & $3.33333^{*}$ & 0.54518 & 0.000 \\
\hline & & Klebsiella pneumoniae (R) & $5.75000^{*}$ & 0.54518 & 0.000 \\
\hline & & $\begin{array}{l}\text { Escherichia coli } \\
\text { (ATCC 25922) }\end{array}$ & 0.33333 & 0.54518 & 0.973 \\
\hline & & Escherichia coli (R) & $3.75000^{*}$ & 0.54518 & 0.000 \\
\hline & & $\begin{array}{c}\text { Staphylococcus aureus } \\
\text { (ATCC 25923) }\end{array}$ & $-3.33333^{*}$ & 0.54518 & 0.000 \\
\hline & \multirow{2}{*}{$\begin{array}{l}\text { Staphylococcus aureus } \\
\text { (MRSA) }\end{array}$} & Klebsiella pneumoniae (R) & $2.41667^{*}$ & 0.54518 & 0.000 \\
\hline & & $\begin{array}{l}\text { Escherichia coli } \\
\text { (ATCC 25922) }\end{array}$ & $-3.00000^{*}$ & 0.54518 & 0.000 \\
\hline & & Escherichia coli (R) & 0.41667 & 0.54518 & 0.940 \\
\hline & \multirow{5}{*}{ Klebsiella pneumoniae (R) } & $\begin{array}{l}\text { Staphylococcus aureus } \\
\text { (ATCC 25923) }\end{array}$ & $-5.75000^{*}$ & 0.54518 & 0.000 \\
\hline & & $\begin{array}{c}\text { Staphylococcus aureus } \\
\text { (MRSA) }\end{array}$ & $-2.41667^{*}$ & 0.54518 & 0.000 \\
\hline & & $\begin{array}{l}\text { Escherichia coli } \\
\text { (ATCC 25922) }\end{array}$ & $-5.41667^{*}$ & 0.54518 & 0.000 \\
\hline & & Escherichia coli (R) & $-2.00000^{*}$ & 0.54518 & 0.005 \\
\hline & & $\begin{array}{l}\text { Staphylococcus aureus } \\
\text { (ATCC 25923) }\end{array}$ & -0.33333 & 0.54518 & 0.973 \\
\hline & \multirow{4}{*}{$\begin{array}{l}\text { Escherichia coli } \\
\text { (ATCC 25922) }\end{array}$} & $\begin{array}{c}\text { Staphylococcus aureus } \\
\text { (MRSA) }\end{array}$ & $3.00000^{*}$ & 0.54518 & 0.000 \\
\hline & & Klebsiella pneumoniae (R) & $5.41667^{*}$ & 0.54518 & 0.000 \\
\hline & & Escherichia coli $(\mathrm{R})$ & $3.41667^{*}$ & 0.54518 & 0.000 \\
\hline & & $\begin{array}{c}\text { Staphylococcus aureus } \\
\text { (ATCC 25923) }\end{array}$ & $-3.75000^{*}$ & 0.54518 & 0.000 \\
\hline & \multirow[t]{3}{*}{ Escherichia coli (R) } & $\begin{array}{c}\text { Staphylococcus aureus } \\
\text { (MRSA) }\end{array}$ & -0.41667 & 0.54518 & 0.940 \\
\hline & & Klebsiella pneumoniae (R) & $2.00000^{*}$ & 0.54518 & 0.005 \\
\hline & & $\begin{array}{l}\text { Escherichia coli } \\
\text { (ATCC 25922) }\end{array}$ & $-3.41667^{*}$ & 0.54518 & 0.000 \\
\hline
\end{tabular}

${ }^{*}$ The mean difference is significant at the 0.05 level.

TABLE 3: Minimum inhibitory concentration (MIC) of honey, ginger extracts, and honey-ginger extract mixtures on susceptible and resistant isolates of the test bacteria species.

\begin{tabular}{lccccccc}
\hline Susceptible bacteria isolate & Honey & G. extract & Mixture & Resistant clinical isolates & Honey & G. extract & Mixture \\
\hline S. aureus (ATCC 25923) & $6.25 \%$ & $6.25 \%$ & $6.25 \%$ & S. aureus (MRSA) & $12.5 \%$ & $12.5 \%$ & $6.25 \%$ \& $12.5 \%$ \\
E. coli (ATCC 25922) & $6.25 \%$ & $6.25 \% \& 12.5 \%$ & $6.25 \%$ & E. coli (R) & $6.25 \%$ \& $12.5 \%$ & $12.5 \%$ & $6.25 \% \& 12.5 \%$ \\
& & & & K. pneumoniae $(\mathrm{R})$ & $6.25 \%$ \& $12.5 \%$ & $12.5 \%$ & $6.25 \% \& 12.5 \%$ \\
\hline at $6.25 \%(0.0625 \mathrm{gm} / \mathrm{mL})$ & $100 \%$ & $75 \%$ & $100 \%$ & & $60 \%$ & $0 \%$ & $75 \%$ \\
$\%$ at $12.50 \%(0.125 \mathrm{gm} / \mathrm{mL})$ & $0 \%$ & $25 \%$ & $0 \%$ & & $40 \%$ & $100 \%$ & $25 \%$ \\
\hline
\end{tabular}

of water soluble antioxidant volatile oils from the ginger powder up on dehydration $[22,33]$. Despite the loss of some antibacterial agents by evaporation during making ginger powder [33], antibacterial agents extracted by the organic solvents were enough to produce inhibition on both susceptible S. aureus ATCC 25923 and E. coli ATCC 25922 (24 mm) that was greater than inhibitions produced by the three positive control antibiotic discs (range: 7-22 mm) (Table 1). According to Clinical and Laboratory Standards Institute
(CLSI) [32] standardization of antibiotic discs, inhibition is considered susceptible if it is $\geq 18 \mathrm{~mm}$ for Amoxicillin $(25 \mu \mathrm{g})$, $\geq 14 \mathrm{~mm}$ for Methicillin $(5 \mu \mathrm{g})$, and $\geq 29 \mathrm{~mm}$ for Penicillin $(10 \mu \mathrm{g})$. The results obtained from amoxicillin discs showed S. aureus (ATCC 25923) to be susceptible as already reported by standardization manual [32]. Very low inhibition results from standard antibiotic discs identified the resistant clinical isolates. The mean $(23.97 \mathrm{~mm} \pm 1.72)$ and range $(19-27 \mathrm{~mm})$ of inhibitions produced by honey-ginger extract mixtures on 
resistant clinical isolates were greater than mean $(6.38 \mathrm{~mm}$ $\pm 5.24)$ and range $(0-14 \mathrm{~mm})$ of antibiotic discs (Methicillin, Amoxicillin, and Penicillin). The inhibitions of ginger powder ethanol/methanol extracts were enhanced $(25.62 \mathrm{~mm} \pm$ 2.55) by mixing with honeys due to their synergistic antibacterial effects of honey-ginger extract mixtures as already reported [10]. The ginger powder ethanol/methanol extracts were positive for known antimicrobial agents such as saponin, alkaloids, phlobatannin, flavonoids, and cardiac glycosides [10]. The antimicrobial effects of different honeys might be related to Phytochemicals such as Phenolic acids (benzoic and cinnamic acids) and flavonoids (flavanones, flavanols) which were reported for significant contribution of the antioxidant capacity of honey that varies greatly depending on the floral sources [34]. The presence of propolis makes stingless honeybees honey slightly different in antimicrobial effect from Apis mellifera honey [35]. Propolis (resinous protective barrier) contains flavonoids, aromatic acids, esters, aldehydes, ketones, fatty acids, terpenes, steroids, amino acids, polysaccharides, hydrocarbons, alcohols, hydroxybenzene, and several other compounds in trace amounts [36]. When Apis mellifera honey (eucalyptus) and stingless honeybees honey were compared, the former had higher phenolic and flavonoid contents than the stingless bee honey which in turn had the higher Antioxidant activity [37]. The antimicrobial effects of different Ethiopian honeys were already evaluated with stingless bees honey producing slightly greater mean inhibition compared to Apis mellifera honey [27]. But Tukey's Honestly Significant Difference (HSD) test (post hoc test) showed absence of significant difference between mean inhibitions of stingless honeybees honey and Apis mellifera honey ( $P=0.964$ ) on susceptible on $S$. aureus (ATCC 25923) and E. coli (ATCC 25922). Many, but not all, of the bacterial strains commonly encountered by humans are killed by flavonoids, even though the mechanism is not yet known [38]. The synergistic antimicrobial effects of honey-ginger extract mixtures might be related chiefly to the increase in volume of these flavonoides in the mixture since both ingredients contained these antimicrobial agents.

Antimicrobial activities (antibacterial, antiviral, antifungal, and antiparasitic) of honeys were reported due to high osmolarity, acidity, hydrogen peroxide, and phytochemicals [39-45]. In vivo use of honey for human as therapeutic agent depends on the evaluation of the nonperoxide phytochemical components of honey as hydrogen peroxide can be destroyed by catalase in the body tissues and serum [46]. Similarly, the high osmolarity and acidity of honeys are destroyed in the digestion system or blood circulation of human. The nonperoxide phytochemical components of Manuka Apinae honey (after removing hydrogen per oxide by treating with enzyme catalase) from New Zealand have been found to have substantial levels of antibacterial activity [47]. Such manuka honey was tested against seven species of bacteria and was found to have MIC (minimum inhibitory concentration) that range from $1.8 \%$ to $10.8 \%$ (v/v) [48]. Probably, oral administration of honey-ginger extract mixture, after clinical evaluation and pharmacological standardization, might be therapeutic for some drug resistant disease causing bacteria strains. The minimum bactericidal concentration (MBC) for this study was $12.5 \%(0.125 \mathrm{~g} / \mathrm{mL})$ for both susceptible and resistant bacteria strains. The minimum inhibitory concentrations (MIC) of honey-ginger extract mixture were $6.25 \%$ $(0.0625 \mathrm{~g} / \mathrm{mL})$ for all $(100 \%)$ susceptible and $75 \%$ resistant bacteria strains (Table 3 ). The fact that both honey and ginger are used in human nutrition and the effectiveness of their mixture as antimicrobial agent at very low concentration make honey-ginger mixture a novel source of effective drug for resistant bacteria strains. Further clinical evaluation and pharmacological standardization of honey-ginger extract mixtures are recommended before using the mixtures against drug resistant bacteria strains for therapeutic purposes.

\section{Conclusion}

In conclusion, honeys-ginger powder extract mixtures were found to have more antimicrobial effect than the use of honeys or ginger extracts solutions individually. The use of honeys and ginger extracts mixtures for drug resistant bacteria such as staphylococcus aureus (MRSA), Escherichia coli (R), and Klebsiella pneumonia (R) is recommended.

\section{Conflict of Interests}

The authors declare that they have no conflict of interests.

\section{Authors' Contribution}

Yalemwork Ewnetu, Wossenseged Lemma, and Nega Birhane participated in selecting the study area and preparing the proposal. Yalemwork Ewnetu carried out the experiment as part of M.S. thesis and Nega Birhane supervised the overall activities and reviewed the documents. Wossenseged Lemma was involved in statistical analysis and preparation of this paper.

\section{Acknowledgments}

We would like to thank University of Gondar for funding this research and Department of Biotechnology for providing us all the facilities during laboratory activities. We gratefully acknowledge Mr Mehari Birhane, M.Sc. student of Department of Biotechnology (University of Gondar), for purchase of white Tigray honey from Adwa town (Tigray region). We would also like to thank Gondar University teaching hospital laboratory for providing the test organisms. Our thanks also go to the laboratory technicians of Department of Biotechnology for their kindly support.

\section{References}

[1] L. Pieters and A. J. Vlietinck, "Bioguided isolation of pharmacologically active plant components, still a valuable strategy for the finding of new lead compounds?" Journal of Ethnopharmacology, vol. 100, no. 1-2, pp. 57-60, 2005.

[2] M. J. Balunas and A. D. Kinghorn, "Drug discovery from medicinal plants," Life Sciences, vol. 78, no. 5, pp. 431-441, 2005. 
[3] World Health Organization (WHO), "Regulatory situation of herbal medicine," A World Wide Review, WHO, Geneva, Switzerland, 1998.

[4] World Health Organization (WHO), General Guidelines for Methodologies on Research and Evaluation of Traditional Medicines, WHO, Geneva, Switzerland, 2000.

[5] K. Kassaye, A. Amberbir, B. Getachew, and Y. Mussema, "A historical overview of traditional medicine practices and policy in Ethiopia," Ethiopian Journal of Health Development, vol. 20, pp. 127-134, 2006.

[6] J. Davies, "Inactivation of antibiotics and the dissemination of resistance genes," Science, vol. 264, no. 5157, pp. 375-382, 1994.

[7] A. Cáceres, L. Fletes, L. Aguilar et al., "Plants used in Guatemala for the treatment of gastrointestinal disorders. 3. Confirmation of activity against enterobacteria of 16 plants," Journal of Ethnopharmacology, vol. 38, no. 1, pp. 31-38, 1993.

[8] A. Osho and O. Bello, "Antimicrobial effect of honey produced by on some common human pathogens Apis mellifera," Asian Journal of Experimental Biological Science, vol. 1, no. 4, pp. 875880,2010

[9] H. D. Une, S. C. Pal, V. S. Kasture, and S. B. Kasture, "Phytochemical constituents and pharmacological profile of Albizzia lebbeck," Journal of Natural Remedies, vol. 1, pp. 1-5, 2001.

[10] F. Omoya and F. Akharaiyi, "Mixture of honey and ginger extract for antibacterial assessment on some clinical isolates," International Journal of Pharmaceutical and Biomedical Research, vol. 2, no. 1, pp. 39-47, 2011.

[11] A. Sebiomo, A. D. Awofodu, A. O. Awosanya, F. E. Awotona, and A. J. Ajayi, "Comparative studies of antibacterial effect of some antibiotics and ginger (Zingiber officinale) on two pathogenic bacteria," Journal of Microbiology and Antimicrobials, vol. 3, pp. $18-22,2011$.

[12] R. V. Patel, V. T. Thaker, and V. K. Patel, "Antimicrobial activity of ginger and honey on isolates of extracted carious teeth during orthodontic treatment," Asian Pacific Journal of Tropical Biomedicine, vol. 1, supplement 1, pp. S58-S61, 2011.

[13] C. Dunford, R. A. Cooper, R. J. White, and P. C. Molan, "The use of honey in wound management," Nursing Standard, vol. 15, no. 11, pp. 63-68, 2000.

[14] C. O. Esimone, F. B. C. Okoye, D. C. Odimegwu, C. S. Nworu, P. O. Oleghe, and P. W. Ejogha, "In vitro antimicrobial evaluation of lozenges containing extract of garlic and ginger," International Journal of Health Research, vol. 3, no. 2, pp. 105110, 2010.

[15] S. D. Jolad, R. C. Lantz, A. M. Solyom, G. J. Chen, R. B. Bates, and B. N. Timmermann, "Fresh organically grown ginger (Zingiber officinale): composition and effects on LPS-induced PGE2 production," Phytochemistry, vol. 65, no. 13, pp. 19371954, 2004.

[16] G. Kumar, L. Karthik, and K. V. Bhaskara Rao, "A review on pharmacological and phytochemical properties of Zingiber officinale Roscoe (Zingiberaceae)," Journal of Pharmacy Research, vol. 4, no. 9, pp. 2963-2966, 2011.

[17] G. A. Otunola, O. B. Oloyede, A. T. Oladiji, and A. J. Afolayan, "Comparative analysis of the chemical composition of three spices-Allium sativum L. Zingiber officinale Rosc. and Capsicum frutescens L. commonly consumed in Nigeria," African Journal of Biotechnology, vol. 9, no. 41, pp. 6927-6931, 2010.

[18] I. Sasidharan and A. N. Menon, "Comparative chemical composition and antimicrobial activity fresh \& dry ginger oils (Zingiber officinale Roscoe)," International Journal of Current Pharmacology Research, vol. 2, no. 4, pp. 40-43, 2010.
[19] S. P. R. Adel and J. Prakash, "Chemical composition and antioxidant properties of ginger root (Zingiber officinale)," Journal of Medicinal Plant Research, vol. 4, no. 24, pp. 2674-2679, 2010.

[20] L. Bao, A. Deng, Z. Li, G. Du, and H. Qin, "Chemical constituents of rhizomes of Zingiber officinale," Zhongguo Zhongyao Zazhi, vol. 35, no. 5, pp. 598-601, 2010.

[21] I. Stoilova, A. Krastanov, A. Stoyanova, P. Denev, and S. Gargova, "Antioxidant activity of a ginger extract (Zingiber officinale)," Food Chemistry, vol. 102, no. 3, pp. 764-770, 2007.

[22] R. Al-Tahtawy, A. El-Bastawesy, M. Monem, Z. Zekry, H. AlMehdar, and M. El-Merzabani, "Antioxidant activity of the volatile oils of Zingiber officinale (ginger)," Spatula DD, vol. 1, no. 1, pp. 1-8, 2011.

[23] T. A. Ajith, V. Nivitha, and S. Usha, "Zingiber officinale Roscoe alone and in combination with $\alpha$-tocopherol protect the kidney against cisplatin-induced acute renal failure," Food and Chemical Toxicology, vol. 45, no. 6, pp. 921-927, 2007.

[24] F. R. Carrasco, G. Schmidt, A. L. Romero et al., "Immunomodulatory activity of Zingiber officinale Roscoe, Salvia officinalis L. and Syzygium aromaticum L. essential oils: evidence for humor- and cell-mediated responses," Journal of Pharmacy and Pharmacology, vol. 61, no. 7, pp. 961-967, 2009.

[25] R. Grzanna, L. Lindmark, and C. G. Frondoza, "Gingeran herbal medicinal product with broad anti-inflammatory actions," Journal of Medicinal Food, vol. 8, no. 2, pp. 125-132, 2005.

[26] Z. Shenkute, Personal Interview with HMC Pharmacy Services Pharmacist on Topic of Ethiopian Traditional Medicine Use in Immigrant Patients, Harborview Medical Center, Seattle, Wash, USA, 2008.

[27] Y. Ewnetu, W. Lemma, and N. Birhane, "Antibacterial effects of Apis mellifera and stingless bees honeys on susceptible and resistant strains of Escherichia coli, Staphylococcus aureus and Klebsiella pneumoniae in Gondar, Northwest Ethiopia," Complementary and Alternative Medicine, vol. 13, p. 269, 2013.

[28] A. Kirakosyan, E. Mitchell Seymour, K. R. Noon et al., "Interactions of antioxidants isolated from tart cherry (Prunus cerasus) fruits," Food Chemistry, vol. 122, no. 1, pp. 78-83, 2010.

[29] R. H. Liu, "Potential synergy of phytochemicals in cancer prevention: mechanism of action," Journal of Nutrition, vol. 134, no. 12, supplement, pp. 3479S-3485S, 2005.

[30] B. Andualem, "Combined antibacterial activity of stingless bee (Apis mellipodae) honey and garlic (Allium sativum) extracts against standard and clinical pathogenic bacteria," Asian Pacific Journal of Tropical Biomedicine, vol. 3, no. 9, pp. 725-731, 2013.

[31] S. P. Malu, G. O. Obochi, E. N. Tawo, and B. E. Nyong, "Antibacterial activity and medicinal properties of Ginger (Zingiber officinale)," Global Journal of Pure and Applied Sciences, vol. 15, no. 3, pp. 365-368, 2009.

[32] Clinical andutic Laboratory Standards Institute (CLSI), "Performance standards for antimicrobial susceptibility testing: seventeenth Information supplement," CLSI Document M100S17, 2007.

[33] J. Roy, D. M. Shakleya, P. S. Callery, and J. G. Thomas, "Chemical constituents and antimicrobial activity of a traditional herbal medicine containing garlic and black cumin," African Journal of Traditional, Complementary and Alternative Medicines, vol. 3, no. 2, pp. 1-7, 2006.

[34] N. Gheldof, X. Wang, and N. J. Engeseth, "Identification and quantification of antioxidant components of honeys from various floral sources," Journal of Agricultural and Food Chemistry, vol. 50, no. 21, pp. 5870-5877, 2002. 
[35] E. Temaru, S. Shimura, K. Amano, and T. Karasawa, "Antibacterial activity of honey from stingless honeybees (Hymenoptera; Apidae; Meliponinae)," Polish Journal of Microbiology, vol. 56, no. 4, pp. 281-285, 2007.

[36] M. Marcucci, "Propolis: chemical composition, biological properties and therapeutic activity," Apidologie, vol. 26, no. 2, pp. 8399, 1995.

[37] D. Bastos, M. C. M. dos Santos, S. Mendonça, and E. A. F. S. Torres, "Antioxidant capacity and phenolic content of stingless bee honey from amazon in comparison to Apis bee honey," in Proceedings of the 2nd International Symposium on Human Health Effects of Fruits and Vegetables, ISHS Acta Horticulturae, 841, Houston, Tex, USA, August 2009, http://www.actahort.org/books/841/index.htm.

[38] A. P. Farnesi, R. Aquino-Ferreira, D. de Jong, J. K. Bastos, and A. E. E. Soares, "Effects of stingless bee and honey bee propolis on four species of bacteria," Genetics and Molecular Research, vol. 8, no. 2, pp. 635-640, 2009.

[39] P. C. Molan, "The antibacterial activity of honey. 1. The nature of the antibacterial activity," Bee World, vol. 73, pp. 5-28, 1992.

[40] P. J. Taormina, B. A. Niemira, and L. R. Beuchat, "Inhibitory activity of honey against foodborne pathogens as influenced by the presence of hydrogen peroxide and level of antioxidant power," International Journal of Food Microbiology, vol. 69, no. 3, pp. 217-225, 2001.

[41] J. W. Fahey and K. K. Stephenson, "Pinostrobin from honey and Thai ginger (Boesenbergia pandurata): a potent flavonoid inducer of mammalian phase 2 chemoprotective and antioxidant enzymes," Journal of Agricultural and Food Chemistry, vol. 50, no. 25, pp. 7472-7476, 2002.

[42] V. Bansal, B. Medhi, and P. Pandhi, "Honey—a remedy rediscovered and its therapeutic utility," Kathmandu University Medical Journal, vol. 3, no. 11, pp. 305-309, 2005.

[43] R. N. Ndip, A. E. Malange Takang, C. M. Echakachi et al., "In-vitro antimicrobial activity of selected honeys on clinical isolates of Helicobacter pylori," African Health Sciences, vol. 7, no. 4, pp. 228-232, 2007.

[44] N. F. Tanih, C. Dube, E. Green et al., "An African perspective on Helicobacter pylori: prevalenc of human infection, drug resistance, and alternative approaches to treatment," Annals of Tropical Medicine and Parasitology, vol. 103, no. 3, pp. 189-204, 2009.

[45] C. E. Manyi-Loh, A. M. Clarke, N. F. Mkwetshana, and R. N. Ndip, "Treatment of Helicobacter pylori infections: mitigating factors and prospective natural remedies," African Journal of Biotechnology, vol. 9, no. 14, pp. 2032-2042, 2010.

[46] C. E. Manyi-Loh, A. M. Clarke, and R. N. Ndip, "An overview of honey: therapeutic properties and contribution in nutrition and human health," African Journal of Microbiology Research, vol. 5, no. 8, pp. 844-852, 2011.

[47] M. Iurlina and F. Rosalia, "Characterization of microorganisms in Argentinean honeys from different sources," International Journal of Food Microbiology, vol. 105, no. 3, pp. 297-304, 2005.

[48] D. J. Willix, P. C. Molan, and C. G. Harfoot, "A comparison of the sensitivity of wound-infecting species of bacteria to the antibacterial activity of manuka honey and other honey," Journal of Applied Bacteriology, vol. 73, no. 5, pp. 388-394, 1992. 


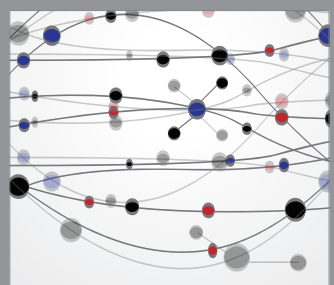

The Scientific World Journal
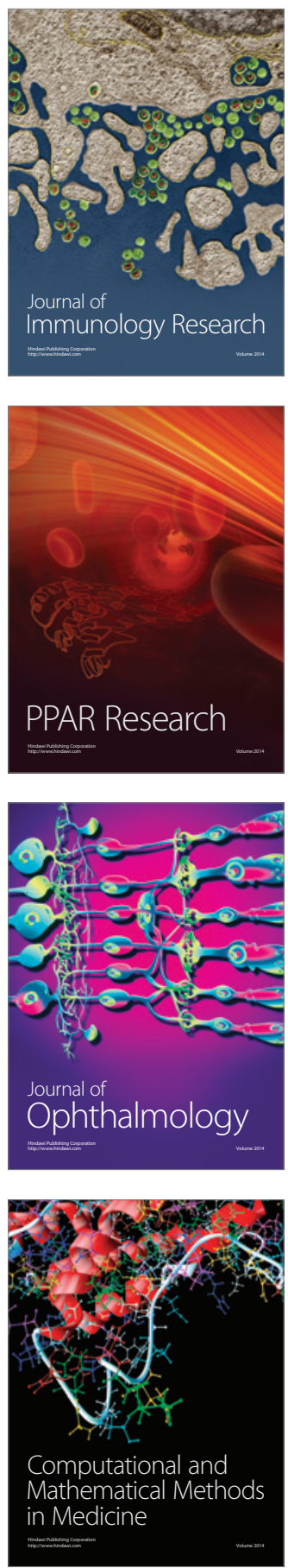

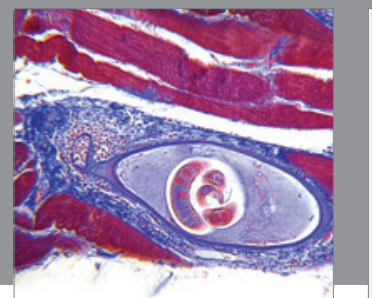

Gastroenterology

Research and Practice
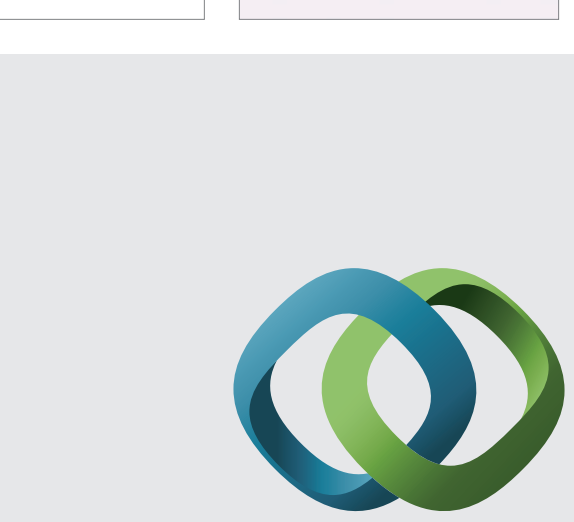

\section{Hindawi}

Submit your manuscripts at

http://www.hindawi.com
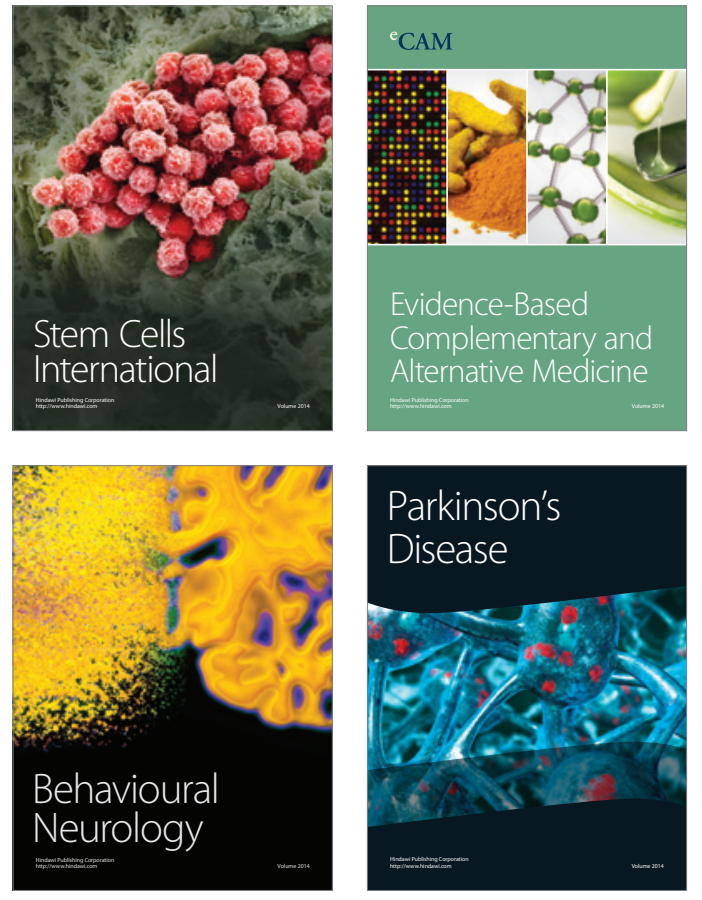
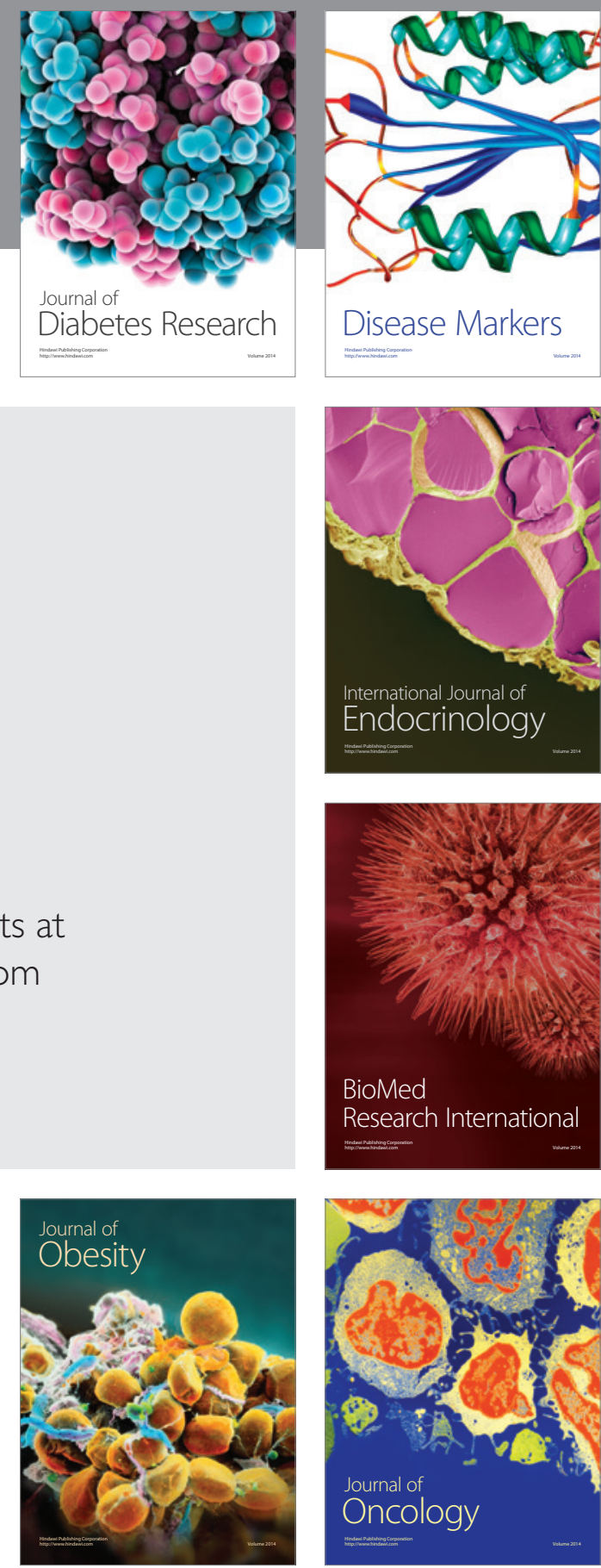

Disease Markers
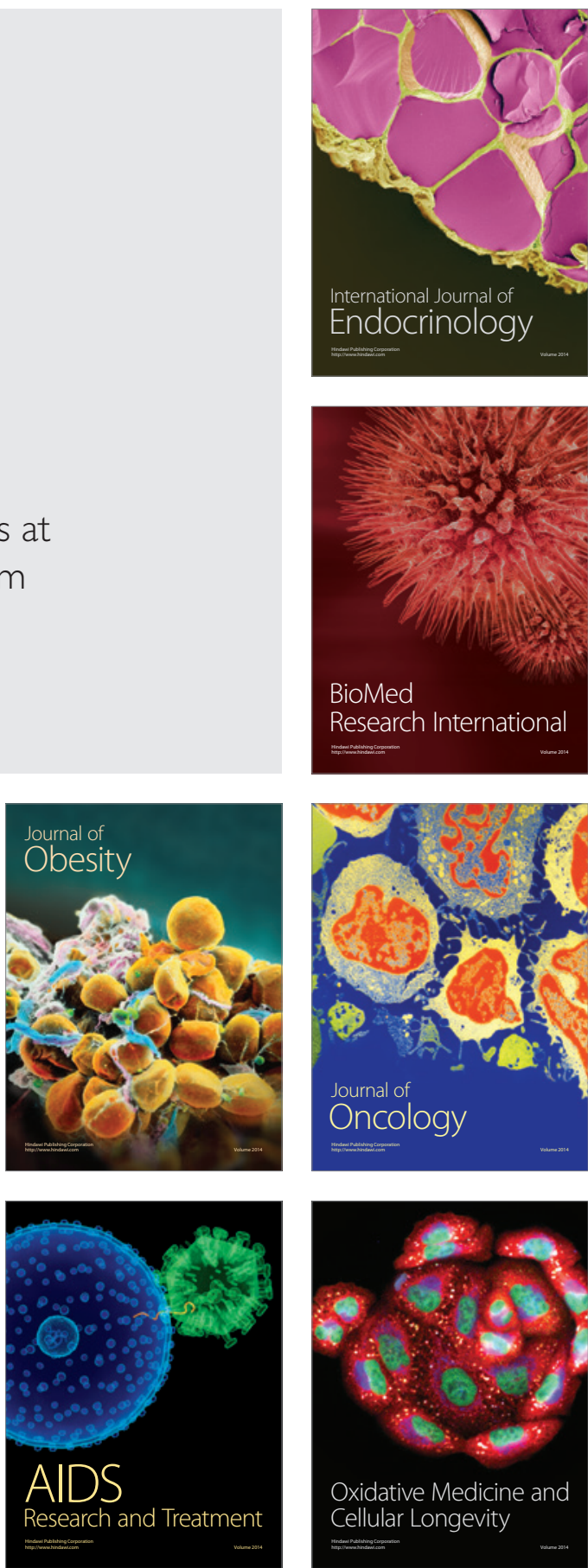